\title{
The Effect of Emotional Contagion, Availability Bias, Overconfidence, Loss Aversion, and Herding on Investment Decisions in the Millennial Generation During the Beginning of the Covid-19 Pandemic
}

\author{
Wisnu Yuwono ${ }^{1}$, Chintia Elmadiani ${ }^{2}$ \\ Universitas Internasional Batam \\ $\left\{\right.$ wisnu@uib.ac.id $\left.{ }^{1}\right\}$
}

\begin{abstract}
The purpose of this study was to analyze the effect of emotional contagion, availability bias, overconfidence, loss aversion, and herding on investment decisions in the millennial generation who live in Batam City, which is an area in Indonesia that has free trade zone and special economic zone facilities. This research is quantitative research with distributing questionnaires, the sample was taken from 220 active millennial investors who invest in stocks. By processing data using software of SmartPLS version 3.2, the results show that availability bias, loss aversion, and herding have a significant positive effect on investment decisions, but emotional contagion and overconfidence bias have no significant effect on investment decisions. The results of this study indicate that millennial investors during the Covid-19 pandemic were still able to think positively and carefully in making the right investment decisions.
\end{abstract}

Keywords: emotional contagion; availability bias; overconfidence; loss aversion; herding; investment decisions

\section{Introduction}

Investors in making investment decisions are always faced with conditions of uncertainty and various risks. Even though investors get data and information about various investment prospects, investors in determining their financial choices will be influenced by behavioral finance factors and interactions with other people (Yuwono \& Erika, 2020). In behavioral finance, one of the psychological factors is behavioral bias, where investors are faced with uncertain conditions (Sabir, Mohammad, \& Shahar, 2019), such as during the early days of Covid-19 which occurred in Indonesia and several stock exchanges in the world that experienced a decline (Ekonomi, 2020).

This research was conducted on investors who were in Batam City at the beginning of the Covid-19 pandemic, this location was chosen because Batam is one of the regions of Indonesia that has free trade zone facilities and special economic zone facilities, so this city is a multi-ethnic city (Saefuloh, 2011) so that Investor behavior finance in the form of crosscultural and national investor interactions will shape the behavioral characteristics of the millennial investors. Some studies on the factors that influence investment decisions are still very interesting to study, moreover, behavioral finance is still rarely studied. In this study, the authors designed a new research model, namely the effect of emotional contagion, availability bias, overconfidence, loss aversion, and herding on investment decisions. Variables studied 
were still showing different results, so it needs to be further investigated, especially when investors are faced with a situation that is not definite at the beginning of the Covid-19 pandemic that hit the stock market.

\section{Literature review}

\subsection{Emotion contagion}

Emotion is one of the factors that influence investors' decision-making. Emotions emerge and underlie the assessment and choices of investment that will be made by potential investors (Lerner, Li, Valdesolo, \& Kassam, 2015). This emotion is a psychological factor that is contagious, which is commonly referred to as emotional contagion. Based on emotional contagion theory (Hatfreld, Cacioppo, \& Rapson, 1993), that the emotions depicted in the form of facial expressions will influence investment decisions. According to Raut \& Kumar (2018), this emotional contagion spreads through negative information such as epidemics and influences investment decisions. In general, emotional contagion is carried out by investors regardless of their experience (Raut \& Kumar, 2018). Emotional contagion succeeds if the direct contact that transmission occurs (Howard, Gengler, Howard, \& Gengler, 2001), but according to Hasford, Hardesty, \& Kidwell (2015) does not always have direct contact or communication with effective, emotional contagion it is relatively permanent. Emotional contagion can also be directly or indirectly affecting judgment, behavior, and teamwork (Barsade, 2002).

$\mathrm{H}_{1}$ Emotional contagion has a significant effect on investment decision

\subsection{Availability Bias}

Availability bias is the tendency of investors to utilize data and information without further review, and prefer to make investment decisions based on the probability of such data and information. Availability bias has a significant effect on investment decisions (Chandra \& Kumar, 2012). This condition occurs when investors rely on information rather than analyze or perform other procedures (Javed, Bagh, \& Razzaq, 2017), and predict the stock price period with based on current prices (Bakar \& Yi, 2016). Availability bias will have a significant positive effect on investment decisions due to the inexperience factor so that they tend to trust the available data (Raut \& Kumar, 2018). This availability bias occurs for all genders, both men and women (Alrabadi, Al-Abdallah, \& Aljarayesh, 2018).

$\mathrm{H}_{2}$ Availability bias has a significant effect on investment decision

\subsection{Overconfidence Bias}

Overconfidence bias has a significant positive effect on investment decisions, is characterized by excessive self-confidence (Chandra \& Kumar, 2012; Ghelichi, Nakhjavan, \& Gharehdaghi, 2016), and ignores any information from other rational investors, because they rely on their knowledge and experience in transactions (Alquraan, Alqisie, \& Al Shorafa, 2016), but sometimes also because of their beliefs with no reason (Grover \& Singh, 2015), and it is the same for all sexes (Bashir, 2013). According to Javed et al. (2017), the relationship positive between variables overconfidence and investment decision because of the behavior of overconfidence that shown by investors, the performance 
of investments also increased. This condition is the opposite, according to Parveen \& Siddiquee (2018) as indicated otherwise, the relationship overconfidence bias with the investment decision is negative, which means that the investor with overconfidence will increasingly bring losses and ses this is a psychological phenomenon, not rationality (Boda \& Sunitha, 2018), and investors feel very confident in their decisions and think they are doing something right (Bakar \& Yi, 2016).

$\mathrm{H}_{3}$ Overconfidence has a significant effect on investment decision

\subsection{Loss Aversion}

Loss aversion is the view of investors who try to stay away from losses and prefer closer to profits. Rational investors will trade more if they are less risk-averse (Barber \& Odean, 2001). Loss aversion has a significant positive effect on investment decisions because investors in the stock market are risk-averse and rational (Mumtaz, Saeed, \& Ramzan, 2018), and try to avoid losses (Chandra \& Kumar, 2012; Grover \& Singh, 2015). Investors become risk-averse if the profit or return from the previous share purchase exceeds the target, and become a risk-seeker if the previous rate of return is a loss (Javed et al., 2017). According to Ghelichi et al. (2016), loss aversion has a negative significance, which means that the more investors are riskseeking, the higher transactions and returns will be.

$\mathrm{H}_{4}$ Loss aversion has a significant positive effect on investment decision Herding

Herding is the behavior of following the movements of the majority of groups and institutions in determining investment decisions (Grover \& Singh, 2015). Herding activities ignore the abilities and confidence of investors themselves and aim to socialize and gain acceptance and recognition from the group. Herding has a significant positive effect because investors who herding show increased performance (Boda \& Sunitha, 2018; Javed et al., 2017). Herding occurs because the market has decreased (Yao, Ma, \& He, 2013). However, for investors who are overconfident and do not join the group, this herding does not have a significant effect (Alquraan et al., 2016; Bakar \& Yi, 2016).

$\mathrm{H}_{5}$ Herding has a significant effect on investment decision

\section{Research methods}

This study is to analyze the relationship between emotional contagion (EC), availability bias (AB), overconfidence (OC), loss aversion (LA), and herding (HD) on investment decisions. The research object is millennial investors (aged 24-40 years) who are actively investing in stocks domiciled in the city of Batam, Riau Islands Province, Indonesia. The number of samples taken was 220 respondents who were distributed through questionnaires between January 2020-March 2020. Each questionnaire contained 22 statements that had to be filled in by respondents. Data analysis used structural equation modeling (SEM) using SmartPLS version 3.0 software. This research model is as shown below: 


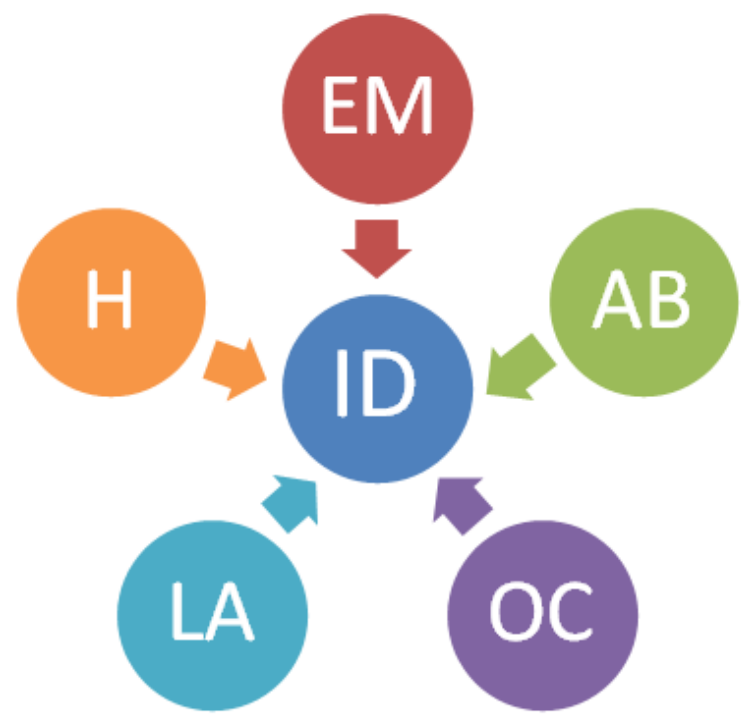

Fig. 1. Research Model

\section{Analysis and Discussion}

\subsection{Demographics of respondents}

Table 1. Demographics of respondents

\begin{tabular}{|c|c|c|}
\hline Information & Freq & Percentage \\
\hline \multicolumn{3}{|l|}{ Sex } \\
\hline Male & 137 & 62,27 \\
\hline Female & 83 & 37,73 \\
\hline \multicolumn{3}{|l|}{ Age } \\
\hline $24-27$ & 69 & 31,36 \\
\hline $28-32$ & 87 & 39,54 \\
\hline$>32-40$ & 67 & 29,10 \\
\hline \multicolumn{3}{|l|}{ Income/month } \\
\hline$<\operatorname{Rp} 5.000 .000$ & 39 & 17,72 \\
\hline Rp 5.000.000 - Rp 7.500.000 & 39 & 17,72 \\
\hline Rp 7.500.001 - Rp 9.000.000 & 91 & 41,36 \\
\hline$>\operatorname{Rp} 9.000 .000$ & 51 & 23,20 \\
\hline
\end{tabular}

\subsection{Validity and Reliability Test}

The validity test in this study used a discriminant validity test, as shown in the table below. The cross-loading value for each statement $>0.7$, when below the value, the statement will be removed from the model. Which means that it fulfills the validity requirements. The reliability test concluded that all the variables used in this study were reliable because the composite reliability and Cronbach's alpha values exceeded 0.7 (Ghozali \& Latan, 2013). 
Table 2. Validity Test

\begin{tabular}{crc}
\hline Statement/ Dimension & Loading factorResult \\
\hline EC 1 & 0,819 & Valid \\
EC 2 & 0,876 & Valid \\
EC 3 & 0,849 & Valid \\
AB 1 & 0,719 & Valid \\
AB 2 & 0,722 & Valid \\
AB 3 & 0,767 & Valid \\
AB 4 & 0,747 & Valid \\
AB 5 & 0,828 & Valid \\
OC 1 & 0,851 & Valid \\
OC 2 & 0,854 & Valid \\
OC 3 & 0,880 & Valid \\
OC 4 & 0,768 & Valid \\
LA 1 & 0,891 & Valid \\
LA 2 & 0,806 & Valid \\
H 2 & 0,915 & Valid \\
H 3 & 0,859 & Valid \\
ID 1 & 0,794 & Valid \\
ID 2 & 0,852 & Valid \\
ID 3 & 0,818 & Valid \\
\hline Source: Primary data, 2021 &
\end{tabular}

Table 3. Reliability Test

\begin{tabular}{cccc}
\hline Variable & Composite Reliability & Cronbach's Alpha & Result \\
\hline Emotional Contagion & 0,883 & 0,801 & Reliable \\
Availability Bias & 0,867 & 0,809 & Reliable \\
Overconfidence & 0,904 & 0,860 & Reliable \\
Loss Aversion & 0,636 & 0,616 & Reliable \\
Herding & 0,879 & 0,730 & Reliable \\
Investment Decision & 0,859 & 0,753 & Reliable \\
\hline
\end{tabular}

Source: Primary data, 2021

\subsection{Hypothesis test results}

The results of the hypothesis test are presented in the table below:

Table 4. Hypothesis test

\begin{tabular}{ccccc}
\hline No & Hypothesis & T Statistics & P-Value & Result \\
\hline 1 & EC - > ID & 0,574 & 0,566 & Rejected \\
2 & AB - ID & 3,761 & 0,000 & Accepted \\
3 & OC - > ID & 1,507 & 0,132 & Rejected \\
4 & LA -> ID & 3,143 & 0,002 & Accepted \\
5 & H - ID & 3,390 & 0,001 & Accepted \\
\hline
\end{tabular}

Source: Primary data, 2021

\section{H1 Emotional contagion has a significant effect on investment decision}

P-value of 0.556 (more than 0.05 ), it can be concluded that emotional contagion has no significant effect on investment decisions. The Indonesia Composite Index, since January 2020 showed a movement below 6,000, and experienced its lowest point in March 2020 at the level of 5.361 since the announcement of the first case of Covid-19 in Indonesia (Ekonomi, 
2020), as well as several stock exchange cases stocks in the world, which contracted at the start of the pandemic, did not determine millennial investment. This is possible due to the limited direct interaction among investors due to lockdown. This result is relevant to the research of Hatfreld et al., (1993), and Howard et al. (2001).

\section{$H_{2}$ Availability bias has a significant effect on investment decision}

P-value of 0,000 (less than 0.05 ), it can be concluded that availability bias has a significant effect on millennial stock investment decisions in Batam city. One of the triggers for this is because millennial investors are relatively young who lack experience, and tend to trust existing data, and they are investors who actively transact through index movements. These results support the research of Chandra \& Kumar (2012), and Raut \& Kumar (2018).

\section{$\mathrm{H}_{3}$ Overconfidence has a significant effect on investment decision}

P-value of 0.132 (more than 0.05), it can be concluded that overconfidence does not have a significant effect on millennial stock investment decisions in Batam city. Millennial investors are not overconfident in making investment decisions. In general, they are rational investors who still consider data and information, and do not rely on their abilities to excess. The results of this study are contrary to the research of Chandra \& Kumar (2012), Ghelichi et al. (2016); Grover \& Singh (2015), and Javed et al. (2017).

\section{$\mathrm{H}_{4}$ Loss aversion has a significant positive effect on investment decision}

P-value is 0.02 (less than 0.05 ), it can be concluded that loss aversion has a significant effect on millennial stock investment decisions in Batam city. During the Covid-19 pandemic, it turns out that millennial investors prefer low-risk investments, because they are aware that economic conditions show uncertainty, and they prefer low returns, as long as it is safe. This supports research of Alquraan et al. (2016), Grover \& Singh, (2015), and Mumtaz et al. (2018).

\section{H5 Herding has a significant effect on investment decision}

Based on the P-value of 0.001 (less than 0.05), it can be concluded that herding has a positive effect on millennial stock investment decisions in Batam city. Millennial investors generally follow group investment decisions and hold discussions with family or colleagues. Investors who do herding tend to increase their investment performance. This is consistent with the research of Boda \& Sunitha (2018), and Javed et al. (2017)

\section{Conclusion}

Availability bias, loss aversion, and herding variables have a significant effect on stock investment decisions for millennials, while emotional contagion and overconfidence have no significant effect on investment decisions. The existence of the Covid-19 outbreak on stock investment decisions for millennials, in general has changed their psychological factors and made investors work more rationally because they are aware that this pandemic makes something uncertain for investment. Suggestions for the next research are that it needs to be 
researched again for the latest conditions related to the determinants of stock investment during the Covid-19 pandemic, considering that this research was conducted at the beginning of the pandemic which may have different results.

\section{References}

[1] Alquraan, T., Alqisie, A., \& Al Shorafa, A. (2016). Do Behavioral Finance Factors Influence Stock Investment Decisions of Individual Investors? (Evidences from Saudi Stock Market). American International Journal of Contemporary Research, 6(3), 159169. Retrieved from www.aijcrnet.com

[2] Alrabadi, D. W. H., Al-Abdallah, S. Y., \& Aljarayesh, N. I. A. (2018). Behavioral Biases And Investment Performance, Does Gender Matter? :, Evidence From Amman Stock Exchange. Jordan Journal of Economic Sciences, 5(1), 77-92. http://doi.org/10.35516/1250-005-001-006

[3] Bakar, S., \& Yi, A. N. C. (2016). The Impact of Psychological Factors on Investors' Decision Making in Malaysian Stock Market: A Case of Klang Valley and Pahang. Procedia Economics and Finance, 35(October 2015), 319-328. http://doi.org/10.1016/s2212-5671(16)00040-x

[4] Barber, B. M., \& Odean, T. (2001). Boys will be Boys: Gender, Overconfidence, and Common Stock Investment. Quarterly Journal of Economics, 116(1), 261-292. http://doi.org/10.2139/ssrn.139415

[5] Barsade, S. G. (2002). The Ripple Effect: Emotional Contagion and Its Influence on Group Behavior Part of the Human Resources Management Commons, and the Organizational Behavior and Theory Commons. Administrative Science Quarterly, 47(4), 644-675. Retrieved from http://repository.upenn.edu/mgmt_papers

[6] Bashir, T. (2013). "Impact of Behavioral Biases on Investo rs Decision Making: Male Vs Female ." IOSR Journal of Business and Management, 10(3), 60-68. Retrieved from http://www.iosrjournals.org/iosr-jbm/papers/Vol10-issue3/G01036068.pdf?id=5073

[7] Boda, J. R., \& Sunitha, G. (2018). Investor's Psychology in Investment Decision Making: A Behavioural Finance Approach. International Journal of Pure and Applied Mathematics, 119(7), 1253-12621. Retrieved from http://www.ijpam.eu

[8] Chandra, A., \& Kumar, R. (2012). Factors Influencing Indian Individual Investor Behaviour: Survey Evidence. SSRN Electronic Journal, 39(3), 1-41. http://doi.org/10.2139/ssrn.2029642

[9] Ekonomi, W. (2020, March 3). Nasib Bursa Global Di Awal 2020, IHSG Lumayan Apes. Warta Ekonomi, pp. 6-8. Retrieved from https://www.wartaekonomi.co.id/read274874/nasib-bursa-global-di-awal-2020-ihsglumayan-apes

[10] Ghelichi, M. A., Nakhjavan, B., \& Gharehdaghi, M. (2016). Impact of Psychological Factors on Investment Decision Making in Stock Exchange Market. Asian Journal of Management Sciences \& Education, 5(July), 36-44.

[11] Ghozali, I., \& Latan, H. (2013). Partial Least Squares: Konsep, teknik dan Aplikasi Menggunakan program SmartPLS 3.0. Badan Penerbit Universitas Diponegoro Semarang.

[12] Grover, P., \& Singh, L. K. (2015). Study on Behavioural Factors Influencing Investment Decision in Real State: A Case Study of Udham Singh Nagar ( Uttrakhand ). International Journal of Engineering Technology, Management and Applied Sciences 
Www.ijetmas.com, 3(7), 150-158.

[13] Hasford, J., Hardesty, D. M., \& Kidwell, B. (2015). More than a Feeling: Emotional Contagion Effects in Persuasive Communication. Journal of Marketing Research, 52(6), 836-847. http://doi.org/10.1509/jmr.13.0081

[14] Hatfreld, E., Cacioppo, J. T., \& Rapson, R. L. (1993). Emotional Contagion. Current Direction in Psycological Science - Cambridge Unviersity Press, 2(3), 96-99. http://doi.org/10.4135/9781452283012.n124

[15] Howard, D. J., Gengler, C., Howard, D. J., \& Gengler, C. (2001). Emotional Contagion Effects on Product Attitudes. Journal of Consumer Research, 28(2), 189-201. Retrieved from http://www.jstor.org/stable/10.1086/322897.

[16] Javed, H., Bagh, T., \& Razzaq, S. (2017). Herding Effects, Over Confidence, Availability Bias and Representativeness as Behavioral Determinants of Perceived Investment Performance: An Empirical Evidence from Pakistan Stock Exchange (PSX). Journal of Global Economics, 06(01), 1-13. http://doi.org/10.4172/2375-389.1000275

[17] Lerner, J. S., Li, Y., Valdesolo, P., \& Kassam, K. (2015). Emotion and Decision Making. Annual Review of Psychology, (June), 1-45. Retrieved from https://scholar.harvard.edu/files/jenniferlerner/files/annual_review_manuscript_june_16 final.final .pdf

[18] Mumtaz, A., Saeed, T., \& Ramzan, M. (2018). Factors affecting investment decisionmaking in Pakistan stock exchange. International Journal of Financial Engineering, 5(4), 1-14. http://doi.org/10.1142/s2424786318500330

[19] Parveen, S., \& Siddiquee, M. (2018). Anchoring Heuristic, Disposition Effect and Overconfidence Bias in Investors: A Case of Pakistan Stock Exchange. Abasyn Journal of Social Sciences, 11(2), 280-294.

[20] Raut, R. K., \& Kumar, R. (2018). Investment Decision-Making Process between Different Groups of Investors: A Study of Indian Stock Market. Asia-Pacific Journal of Management Research and Innovation, 14(1-2), 39-49. http://doi.org/10.1177/2319510x18813770

[21] Sabir, S. A., Mohammad, H. Bin, \& Shahar, H. B. K. (2019). The role of overconfidence and past investment experience in herding behaviour with a moderating effect of financial literacy: Evidence from pakistan stock exchange. Asian Economic and Financial Review, 9(4), 480-490. http://doi.org/10.18488/journal.aefr.2019.94.480.490

[22] Saefuloh, A. A. (2011). Kebijakan Ketenagakerjaan pada Sektor Industri di Kota Batam. Kajian, 16(1), 189-217. Retrieved from https://jurnal.dpr.go.id/index.php/kajian/article/view/522

[23] Yao, J., Ma, C., \& He, W. P. (2013). Investor herding behaviour of Chinese stock market. International Review of Economics and Finance, 29(C), 12-29. http://doi.org/10.1016/j.iref.2013.03.002

[24] Yuwono, W., \& Erika. (2020). Analisis pengaruh citra perusahaan, informasi akuntansi, informasi netral, rekomendasi penasehat dan kebutuhan finansial terhadap keputusan investasi di pasar modal. Seiko: Journal of Management \& Business, 3(3), 143-155. http://doi.org/10.37531/sejaman.v3i3.735 